[測粉科学 第 20 巻 第 1 号 (1973)]

研究ノート

\title{
純水およびナイロンクロスを利用した ミキサーによる馬鈴薯澱粉の採取法
}

\author{
矢木 敏 博* 吉 岡 真 一** \\ (昭和 47 年11月 14 日受理)
}

\author{
Studies on the Preparation of Potato Starch \\ Toshihiro YAGI* and Shinichi YosHIOKA** \\ * Memuro Starch Factory, Hokuren (The Federation of Agricultural \\ ** The Hokkaido National Agricultural Experiment Station
} Cooperative Societies of Hokkaido)

\begin{abstract}
A special feature in this method is to use nylon cloth bag called Hyzex in stead of standard sieve.

As the result, preparation of about 40 varieties become possible a day, recovery became higher too.
\end{abstract}

\section{ま え がき}

植物体より実験室的規模で粗溊粉を採取するため, ミ キサーで植物組織を磨砕し, 磨砕乳から植物繊維類を篩 で分離し，沈殿物を水洗する方法が一般的に行なわれ， とくに甘藷ではこれを歩留り算定に利用しようとの意図 から詳細な検討1 3)が行なわれている。なお各種の澱粉 で, 精製の諸操作 ${ }^{3}$ がつけ加えられる。

一方, 馬鈴䈌の場合は澱粉含量測定法としてはライマ ン秤による比重測定が実用され, 酸分解による測粉の分 析を加味して, 換算表を作成している。ところが, 澱粉 の性質を調查するため, 原料馬鈴薯から澱粉を採取する 方法の発表はいまだ行なわれていない。

筆者らは馬鈴罾澱粉の品質検討の一つとして, 溊粉の 灰分含量の調查)に着手したが，現在工場に集荷される 原料馬鈴整は, 土壤条件, 収穫時期, 品種, 栽培条件な ど複雑な環境から収穫されてくるため, これらの条件を 解明するには, 栽培条件の明確な原料馬鈴翇について,

* ホクレン芽室澱粉工場（河西郡芽室町西園町）

** 農林省北海道農業試験場畑作部（河西郡芽室町新 生)
ある程度の多数の試料を扱う必要がある。

かかる場合, 従来の篩による粕分離法ではかなりの時 間を要し，多数の試料を扱えず，かつ水道水の使用が澱 粉の無機物組成にかなり大きく影響することを知った。

このため, 用水と粕分離法について種々検討し, 用水 は純水を用い, 粕分離はナイロンクロスの袋を使い, さ らに土肉分離法を考案して，均一条件下の試料澱粉が得 られるよう, 各操作の処理時間, 処理法, 用水量等を規 定して一つの方法を組み立てて, 溊粉の採取を行なっ た。このような試料採取は育種試験等にも適用できると 思われる。

溉粉研究の進展につれて, 目的が変れば, 採取法にも なお改善の余地はあると考え, 今回は, ミキサーを使っ て馬鈴㯰から澱粉試料を採取する方法について紹介する しだいである。

\section{1. 澱粉の採取法}

1. 原料馬鈴著および用具等

1）原料馬鈴薯

塊茎個体間の変動が知られているので, 品種の特徵を 備えた, 用途に適合した原料を選定する。原料 $2 \sim 3 \mathrm{~kg}$ 
をよく水洗し, 必要に応じ, 澱粉含有率をライマン秤法 で測定しておく。

2) 用 水

用水の水質が製品の品質に影響するので，目的により 純水を用いる。用水の水温は約 $15^{\circ} \mathrm{C}$ を標準とし，1点 $15 l$ を準備する。

3) 用具 (20 点 2 反覆の場合)

純水採取装置, 水槽 (計 $600 l$ ), ポリバケッ $4 \sim 5$ 個, $2 l$ 手付ポリビーカー

包丁, まな板, ボール ( $3 l$ 容位 3 個)

$1 \mathrm{~kg}$ 上四天秤

ミキサー, ストップウォッチ

ボール (10l 容 13 個), ナイロンクロス製袋 $(20 \times 25$ $\mathrm{cm}$ ，ハイゼックス網 150 目〔126 メッシュ，オープニン グ $140 \mu$ 〕を使用, 40 枚), ポリバケッ (10 $l$ 容, 20 個), 笊, ナイロンクロス $(50 \times 50 \mathrm{~cm}$ ぐらい, ハイゼックス 網 180 目 [144×100 メッシュ]使用, $3 \sim 4$ 枚)

ポリビーカー ( $1 l$ 容 40 個 $),$ ビーカー $(100 \mathrm{ml}$ 容, 40 個), 滤紙 $(20 \mathrm{~cm}$ 角, 縁を折り箱にする。 40 個), コ一 ヒーミル。

洗浄瓶 3 個、スパチュラ（先を平らにしたものと普通 のもの)，掛時計等。

4) 作業員

20 点 2 反覆に 6 名程度。

\section{2. 澱粉の採取法}

1) 磨 砕

馬鈴整は頂部と基部を貫いて，縦割りし， $1 / 2$ 量を細 切し, よく混合し, $400 \mathrm{~g}$ を取り, 用水 $300 \mathrm{~m} l$ を加え, ミキサーで正確に 1 分 40 秒磿砕する。

2) 分 離

磨砕物は $1 l$ の用水を使って, ナイロンクロスの袋に 移し，口をしばり， $3 l, 3 l, 2 l$ の用水を入れた $10 l$ 容 のボールの中で, 順次絞り出しを行なう。1,2 回目のボ 一ル中に測粉の大部分が移る。3 個のボールの内容物を 合一し，30 分間静置する。袋の中の粕は通風乾燥して科 量, 風袋を差引くことにより, 粕の重量がわかる。粕の 必要のないときはよく洗って, 再度使用する。

3) 洗 浄

静置後, 静かに泡をすくい取り, 傾潟して上澄液を捨 てる。これに用水 $1 l$ を加え, 撹拌し, $10 l$ のポリバケ ツにポリ製衃を乗せ，ナイロンクロスを敷いて，この測 粉乳をこし, 用水 $3 l$ でクロス上を洗浄する。 1 時間静 置後, 上澄液を傾潟し, $1 l$ 容ビーカーに澱粉を移し, 標線まで用水を加え，擋拌し， 4 時間静置する。

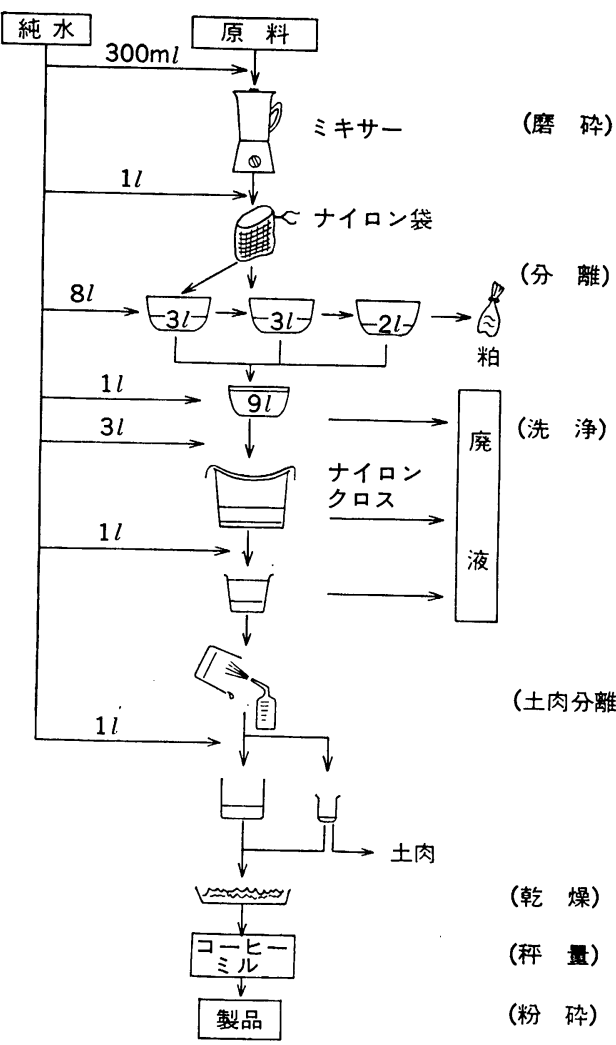

図 1. 澱粉採取法

4）土肉分離および乾燥

4 時間後, 傾潟し, 表面の土肉部分 (約 $1 \mathrm{~mm}$ の厚 さ）を, 洗浄瓶を使って, $100 \mathrm{~m} l$ 容ビーカーに洗い流 し, 用水を加え, よく擋拌し, 一夜放置する。また $1 l$ 容 ビーカーにも用水 $500 \mathrm{~m} l$ を加えて擋拌し, 静置する。 翌朝上澄液を捨て, $100 \mathrm{~m} l$ のビーカーの沈殿物は濾紙 片で水分を取り，先を平らにしたスパチュラで土肉部分 を搔き取り, 薬包紙に包み, 乾燥秤量する。底の少量の 澱粉は $1 l$ ビーカーの澱粉とともに, 清浄な滤紙でつく った箱に移し, 通風のよい所で, 自然乾燥する。

5) 粉 砕

秤量後, コーヒーミルで粉砕, 貯蔵する。

以上の諸作業のうち, 磨砕から粕分離・洗浄までを 1 日で行ない，各処理時間を正確に実施する。自然乾燥は $2 \sim 3$ 日行ない, 水分 15２0\% 程度になるよう心がけ た。したがって, 原料点数 $20 \sim 30$ 点につき, 水洗いお よび水中重測定など準備 1 日, 磨砕・分離・洗浄 1 日, 土肉分離半日, 乾燥・秤量・粉砕 $3 \sim 4$ 日で分析可能と なる。 
表 1 . 採 取 結 果

（乾物/馬鈴暮）

\begin{tabular}{|c|c|c|c|c|c|c|c|c|c|c|}
\hline \multirow{2}{*}{ 品 種 名 } & \multirow{2}{*}{ No. } & & 取 & & \multirow{2}{*}{$\begin{array}{c}\text { 澱粉 } \\
\text { 含有率 } \\
\text { \% }\end{array}$} & \multirow{2}{*}{$\begin{array}{c}\text { 澱粉重 } \\
\%\end{array}$} & \multirow{2}{*}{$\begin{array}{c}\text { 澱 粉 } \\
\text { 回収率 } \\
\% \\
\text { \% }\end{array}$} & \multirow{2}{*}{$\begin{array}{c} \pm \text { 肉 } \\
\%\end{array}$} & \multirow{2}{*}{$\begin{array}{l}\text { 粕 } \\
\%\end{array}$} & \multirow{2}{*}{ 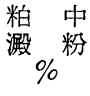 } \\
\hline & & 試料重 $\mathrm{g}$ & 粕 分 離* & 用 水 & & & & & & \\
\hline \multirow{5}{*}{ 紅 丸 } & 1 & 600 & 標 準 飾 & 純 水 & 15.75 & 13.51 & 86 & 0.40 & 4.6 & 2.2 \\
\hline & 2 & " & ナイロンクロス袋 & " & " & 13.94 & 89 & 0.41 & 4.4 & 2.1 \\
\hline & 3 & 400 & " & "1 & " & 15.06 & 96 & 0.33 & 3.2 & 1.5 \\
\hline & 4 & 800 & " & " & " & 12.39 & 79 & 0.41 & 7.0 & 2.7 \\
\hline & 5 & 600 & " & 井戸水 ${ }^{\dagger}$ & " & 13.46 & 85 & 0.40 & 4.9 & 2.6 \\
\hline \multirow{5}{*}{$x=ワ$} & 6 & 600 & 標 準 節 & 純 水 & 19.74 & 18.34 & 93 & 0.71 & 4.1 & 1.9 \\
\hline & 7 & "I & ナイロンクロス袋 & "I & "I & 17.95 & 91 & 0.67 & 4.3 & 2.1 \\
\hline & 8 & 400 & " & " & " & 18.11 & 92 & 0.67 & 2.9 & 1.3 \\
\hline & 9 & 800 & $\prime \prime$ & " & " & 17.15 & 87 & 0.53 & 6.1 & 3.2 \\
\hline & 10 & 600 & " & 井戸水 ${ }^{\dagger}$ & " & 17.11 & 87 & 0.46 & 4.9 & 2.7 \\
\hline
\end{tabular}

* 標準節は従来法, ナイロンクロス袋は本ノートの方法

†井戸水 $\left(\mathrm{SiO}_{2} 52, \mathrm{CaO} 12.7, \mathrm{MgO} 5.4, \mathrm{~K}_{2} \mathrm{O} 0.7 \mathrm{ppm}\right)$

表 2. 澱 粉 の 品 質

（水分 $18 \%$ 換算）

\begin{tabular}{|c|c|c|c|c|c|c|c|c|c|c|c|}
\hline \multirow{2}{*}{ 品種名 } & \multirow{2}{*}{ No. } & \multirow{2}{*}{ 白 度* } & \multirow{2}{*}{\multicolumn{2}{|c|}{$\begin{array}{c}\text { 粗蛋白質 灰 } \text { 分 } \\
\mathrm{mg} \% \%\end{array}$}} & \multicolumn{4}{|c|}{ 無機物組 成 (mg \%) } & \multicolumn{3}{|c|}{ 粘 度 特 性 ${ }^{\dagger}$} \\
\hline & & & & & $\mathrm{P}$ & $\mathrm{K}$ & $\mathrm{Mg}$ & $\mathrm{Ca}$ & $\begin{array}{l}\text { 糊化開始 } \\
\text { 温度 }{ }^{\circ} \mathrm{C}\end{array}$ & $\begin{array}{c}\text { 最高粘度 } \\
\text { B.U }\end{array}$ & $\begin{array}{l}\text { 最高粘度到 } \\
\text { 達温度 }{ }^{\circ} \mathrm{C}\end{array}$ \\
\hline \multirow{5}{*}{ 紅 丸 } & 1 & 93.5 & & 0.186 & 58 & 35 & 5.2 & 0.9 & & & \\
\hline & 2 & 94.5 & 85 & 0.185 & 57 & 35 & 6.3 & 1.4 & 62.0 & 1460 & 72.0 \\
\hline & 3 & 93.5 & & 0.193 & 57 & 33 & 6.5 & 2.1 & & & \\
\hline & 4 & 94.5 & & 0.188 & 57 & 36 & 6.3 & 1.4 & & & \\
\hline & 5 & 94.0 & 64 & 0.217 & 56 & 5.8 & 11.5 & 24.2 & 62.5 & 1080 & 86.0 \\
\hline \multirow{5}{*}{$x=\eta$} & 6 & 93.5 & & 0.291 & 87 & 63 & 8.1 & 1.4 & & & \\
\hline & 7 & 94.5 & 79 & 0.291 & 86 & 61 & 10.5 & 1.3 & 64.0 & 1650 & 68.0 \\
\hline & 8 & 94.5 & & 0.294 & 88 & 58 & 11.0 & 1.4 & & & \\
\hline & 9 & 93.5 & & 0.305 & 90 & 68 & 8.7 & 1.2 & & & \\
\hline & 10 & 93.5 & 73 & 0.321 & 88 & 23.0 & 16.7 & 28.2 & 60.0 & 1570 & 73.5 \\
\hline
\end{tabular}

* Kett 白度計による。

†ブラベンダーフミログラフによる。

\section{2. 試験成績および考察}

採取試験の一例として, 表 1 を示した。澱粉含有率 15.75 の紅丸および 19.74 のエニワを使い, 試料重量, 用水, 粕分離等を試験した。結果は 2 回の平均值であ り，テストはこの採取法を検討した当時のものである。 澱粉含有率に対する採取した港粉の割合を回収率とす れば試料重 $400 \mathrm{~g}$ では $90 \%$ 以上を示し， $600 \mathrm{~g} ， 800 \mathrm{~g}$ では若干低下寸る場合もみら礼る。これに対し，粕ある いは粕の測粉が増している。
そこで, 回収率 $90 \%$ 以上にすることと, 分析試料の 確保といら点から， $400 \mathrm{~g}$ を標準とした。なお馬鈴薯中 の澱粉を完全に回収するためには, 試料重をさらに少な くし, 傾潟した廃水や分離した土肉, 粕中の澱粉の再回 収を行なら必要があろう。しかし，この方法ではつとめ て一定条件下で採取を行ならので, たとえば糖化した馬 鈴薯や腐敗薯の歩留り, 育種材料の選抜テストには反覆 回数さえ吟味すればかなりの精度で実用し得ると思われ る。

土肉の割合は品種により若干異なるようである。 
従来の篩を使う方法では粕の洗浄分離に 20 30 分を 要したが, この方法では $3 \sim 4$ 分で実施できる。 つぎに採取した品質を表 2 のような項目で調べた。 前述のように, この採取法は澱粉の品質を調べるた め, 土肉分離をきびしく行なったので，白度は 93.5 94.5 とかなり高く, かつ粗蛋白質含量は低い。 灰分含量は紅丸で $0.18 \sim 0.19 \%$ ，エニワで 0.29 $0.30 \%$ 程度を示した。井戸水を使用して採取した溉粉 は $550^{\circ} \mathrm{C}$ ではきれいに灰化しないため, 若干高い值を 示した。

無機物組成中リン酸は用水の差が少ないが，カリウ ム, マグネシウム, カルシウムでは用水の影響が大きく 現われている。試料重の影響を見ると, リン酸では一定 の傾向は見られないが，カリウムは $400 \mathrm{~g}$ でやや少な
W。

粘度特性においても, 品種差や用水の差が鋭敏に現わ れた。とくに品種による B. U の高低と用水の影響は興 味深い。

なおミキサーの最高速回転は避けたが, 鏡検した範囲 では損傷した澱粉粒は見られなかった。

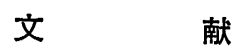

1）小野田正利：澱粉工誌， 3，76 (1955).

2) 前沢辰雄, 早川幸雄: 農加技研誌, 4, 3 (1957).

3）二国二郎編：デンプンハンドブック，197，358, 399.

4) 矢木敏博, 下村 司, 吉岡真一: 澱粉科学, 19, 3 (1972). 